DOMINGUES, A. A.; SANTOS, A. J. M.; BACKES, C.; RODRIGUES, L. M.; TEODORO, A. G.; BESSA, S. V.; RIBON, A. A.; GIONGO, P. R.; GODOY, L. J. G.; RESENDE, C. C. F. Nitrogen fertilization of paiaguás grass: production and nutrition. Revista de Agricultura Neotropical, Cassilândia-MS, v. 8, n. 2, e5918, abr./jun. 2021. ISSN 2358-6303. DOI: https://doi.org/10.32404/rean.v8i2.5918.

\title{
Nitrogen fertilization of paiaguás grass: production and nutrition
}

\author{
Alexandre Alves Domingues ${ }^{1}$, Alessandro José Marques Santos ${ }^{1}$, Clarice Backes ${ }^{1}$, Lucas \\ Matheus Rodrigues ${ }^{1}$, Arthur Gabriel Teodoro², Stephanie Vicente Bessa ${ }^{1}$, Adriana Aparecida \\ Ribon $^{3}$, Pedro Rogério Giongo ${ }^{4}$, Leandro José Grava de Godoy ${ }^{5}$, Cinthya Cristina Fernandes \\ de Resende ${ }^{1}$
}

\begin{abstract}
${ }^{1}$ Universidade Estadual de Goiás, Câmpus Oeste, São Luís de Montes Belos, Goiás, Brasil. E-mail: alexandrezootec@yahoo.com.br, alessandro.santos@ueg.br, clarice.backes@ueg.br, stephaniebessa86@gmail.com, lucasmrzoo@gmail.com,

cinthyaresende@hotmail.com
\end{abstract}

${ }^{2}$ Universidade Federal de Goiás, Campus Samambaia, Goiânia, Goiás, Brasil. E-mail: arthur_teodoro@hotmail.com

${ }^{3}$ Universidade Estadual de Goiás, Unidade Universitária de Palmeiras, Palmeiras de Goiás, Goiás, Brasil. E-mail: adriana.ribon@ueg.br

${ }^{4}$ Universidade Estadual de Goiás, Unidade Universitária de Santa Helena, Santa Helena de Goiás, Brasil. E-mail: pedro.giongo@ueg.br

${ }^{5}$ Universidade Estadual Paulista, Campus de Registro, Registro, São Paulo. Brasil. E-mail: leandro.grava@gmail.com

Received: 01/03/2021; Accepted: 11/06/2021.

\begin{abstract}
Nitrogen $(\mathrm{N})$ is a nutrient associated with the development of plant shoots, which makes it a vitally important element for the maintenance and sustainability of pasture. The goal of this study was to evaluate the effects of nitrogen fertilization on the productive and nutritional traits of Urochloa brizantha Paiaguás, as well as the efficiency of digital imaging and the use of a chlorophyll meter in obtaining green color indices. The experiment was conducted in the field on the Escola farmat the State University of Goiás, located in São Luís de Montes Belos, GO. A randomized-block design with five treatments and four replicates was adopted. Treatments consisted of four $\mathrm{N}$ rates $\left(0,75,150,300\right.$, and $\left.600 \mathrm{~kg} \mathrm{ha}^{-1}\right)$ in the form of ammonium sulfate. The grass res ponded up to the $\mathrm{N}$ rate of $374 \mathrm{~kg} \mathrm{ha}^{-1}$ for production-related traits, such as plant height, number of tillers, and shoot dry matter. Maximum dry matter yields were 21,225 and $13,710 \mathrm{~kg} \mathrm{ha}^{-1}$ year-1 for the first and second cycles, respectively. Both the chlorophyll meter and digital imaging were efficient in indicating plant $\mathrm{N}$ nutritional status. Paiaguás grass responds to $\mathrm{N}$ similarly to other Urochloa brizantha cultivars.
\end{abstract}

Keywords: Chlorophyll meter, Digital imaging, Color indices, Ni trogen, Pasture.

\section{Adubação nitrogenada em capim-paiaguás: produção e nutrição.}

\section{RESUMO}

O nitrogênio $(\mathrm{N})$ é um nutriente associado ao desenvolvimento da parte aérea da planta, acúmulo de massa, produção de folhas e perfilhos, sendo de vital importância para manutenção e sustentabilidade da pastagem. Objetivou-se com esse trabalho avaliar o efeito da adubação nitrogenada nas características produtivas e nutricionais na Uroclhoa brizantha cv. Paiaguás, bem como a eficiência da imagem digital e uso do clorofilômetro na obtenção de índices de cor verde. O experimento foi conduzido em campo, na Fazenda Escola da Universidade Estadual de Goiás, Câmpus São Luís de Montes Belos, GO. O delineamento utilizado foi o de blocos casualizados, com cinco tratamentos e quatro repetições. Os tratamentos foram compostos por cinco doses de $\mathrm{N}(0,75,150,300$ e $600 \mathrm{~kg}$ ha-1) na forma de sulfato de amônio. O capim-paiaguás respondeu até a dose de $374 \mathrm{~kg}$ ha-1 de N para as características produtivas como altura de plantas, número de perfilhos e massa seca da parte aérea. As máximas produtividades obtidas foram de 21.225 e $13.710 \mathrm{~kg} \mathrm{ha}^{-1} \mathrm{ano}^{-1}$ de MS para o primeiro e segundo ciclo, respectivamente. Tanto o clorofilômetro como a imagem digital foram eficientes para indicar o estado nutricional da planta em N. O capim-paiaguás responde ao $\mathrm{N}$ de forma semelhante às demais Uroclhoas brizantha.

Palavras-chave: Clorofilômetro, Imagem digital, Índices de cor, Nitrogênio. Uroclhoa brizantha, Produtividade de pastagem. 


\section{Introduction}

Pasture farming is a multi-purpose activity in certain situations, such as monocropping, intercropping, and succession. However, its ultimate purpose is to fully or partially constitute the diet of beef (Reis et al. 2009) and dairy cattle (Gonçalves et al. 2009), protect the soil, provide organic matter, and promote the maintenance of soil fertility and physical conditions. (Costa et al. 2013).

Brazil has the second largest cattle herd in the world and is also the largest producer and second primary exporter of beef (USDA 2017) with 7.77 billion tons of beef produced in 2020 (IBGE, 2020a). It is also ranked fourth for its dairy herd, constituting the fourth largest milk producer (USDA 2016) with the production of 34.85 billion liters of milk in 2020 (IBGE, 2020b). Most cattle are reared on pasture for meat (Ferraz and Felício 2010) and milk (Abdala et al. 1999).

Urochloa brizantha BRS Paiaguás is a cultivar released by EMBRAPA in 2013 that develops in mediumfertility soils and adapts well to integrated systems. It is also characterized as having a high production potential during the dry period of the year (EMBRAPA 2013). Detmann et al. (2014) demonstrated that, in Brazil, during the dry season, there is an deficiency of nitrogen compounds in plants, mainly protein.

Therefore, supplementation during this time is necessary such that plant requirements can be met and production goals are achieved. Thus, increasing the nutrient content of the forage is a crucial step in reducing the costs of supplementation. Given the importance of fertilization management, a technology with easy access by both technicians and producers is digital imaging, which can aid in the management of pastures through the use of cameras and smartphones (Mcroberts et al. 2016). Based on the green color obtained from the image, which is related to the plant $\mathrm{N}$ content, the images can be used as a tool to evaluate nitrogen fertilization, as shown by Lima et al. (2012) with Bermuda grass.

Backes et al. (2010) with Zoysiagrass, and Simões et al. (2015) with Tifton 85. Another available technology is the instrument used to measure chlorophyll, known as chlorophyll meters, which are important considering that the chlorophyll content of a plant indicates its $\mathrm{N}$ nutritional status (Viana et al. 2014).

The objective of this study was to evaluate effects of nitrogen fertilization on the productive and nutritional traits of U. brizantha Paiaguás and the efficiency of digital imaging and chlorophyll meters in obtaining green color indices.

\section{Material and Methods}

The experiment was conducted in the field on the Escola farm at the State University of Goiás, located in São Luís de Montes Belos, GO, Brazil (16³2'30"S, $50^{\circ} 25^{\prime} 21^{\prime \prime} \mathrm{W} ; 569 \mathrm{~m}$ altitude). The climate in the region is an Aw type, according to the Köppen classification, with an average temperature of $23.5^{\circ} \mathrm{C}$ and an average annual precipitation of $1785 \mathrm{~mm}$, which is concentrated between the months of October and March (Alvares et al. 2014). Temperature and precipitation data collected during the experiment are presented in Figure 1

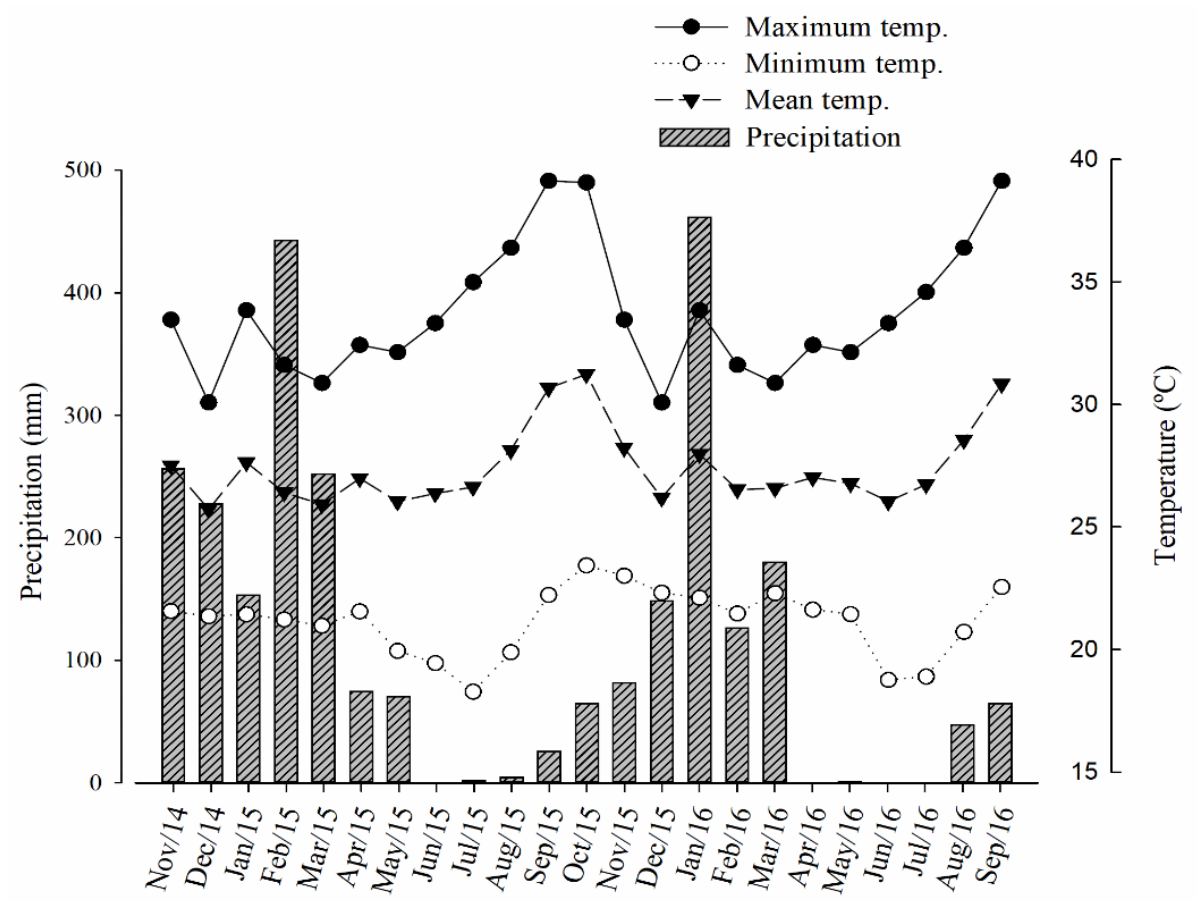

Figure 1. Maximum, minimum, and mean temperature and precipitation data obtained during the experimental period. 
The soil where the experiment was implemented was classified as a Dystrophic Red Latosol with a 45\% clayey texture, in a mild wavy relief (EMBRAPA 2013). For the initial chemical characterization, samples were collected from the entire experimental area at a depth of 0-0.20 m, following Raij et al. (2001), and the following results were obtained: $\mathrm{pH}\left(\mathrm{CaCl}_{2}\right)$ 5.8; $48 \mathrm{~g} \mathrm{dm}^{-3}$ organic matter; $5 \mathrm{mg} \mathrm{dm}^{-3} \mathrm{P}$ resin; $71 \%$ base saturation; and 22, 1.1, 45, and $7 \mathrm{mmol}_{\mathrm{c}} \mathrm{dm}^{-3} \mathrm{H}^{+}+\mathrm{Al}^{+3}, \mathrm{~K}, \mathrm{Ca}$, and $\mathrm{Mg}$, respectively.

The forage species used in the experiment was Paiaguás grass (U. brizantha (Hochst. ex A. Rich.) R. D. Webster Paiaguás [syn. Brachiaria brizantha (Hochst.ex A. Rich.] Stapf Paiaguás), BRS Paiaguás. The experimental area was prepared conventionally with one plowing and two harrowings; subsequently, the forage was sown at a seed density of $6.5 \mathrm{~kg} \mathrm{ha}^{-1}$, representing $50 \%$ of pure live seed. Based on the soil analysis, there was no need for liming. For base fertilization (formation), the soil received $100 \mathrm{~kg} \quad \mathrm{ha}^{-1} \quad \mathrm{P}_{2} \mathrm{O}_{5}$ as triple superphosphate and $60 \mathrm{~kg} \mathrm{ha}^{-1} \mathrm{~K}_{2} \mathrm{O}$ in the form of potassium chloride. At 40 days after sowing, $40 \mathrm{~kg} \mathrm{ha}^{-1}$ $\mathrm{N}$ was added in the form of ammonium sulfate. After the establishment of the pasture, a uniformity cut was made, residual material was removed, and experimental plots (2 $\mathrm{m}^{2}$ each) were allocated with $0.5 \mathrm{~m}$ spacing.

A completely randomized design with five treatments and four replicates was adopted. Treatments consisted of five $\mathrm{N}$ rates $(0,75,150,300$, and $600 \mathrm{~kg}$ $\mathrm{ha}^{-1}$ ) in the form of ammonium sulfate. In the 2 years of evaluation, nitrogen fertilization (corresponding to each treatment) was split into three sessions (during the rainy period), soon after the forage was lowered. In each session, the soil also received $40 \mathrm{~kg} \mathrm{ha}^{-1} \mathrm{~K}_{2} \mathrm{O}$, totaling $120 \mathrm{~kg} \mathrm{ha}^{-1} \mathrm{yr}^{-1}$.

The periods of evaluation of the structural and productive traits were distributed as follows: first year, January, March, April (rainy season), and August (dry season); second year, January, March, April (rainy season), and September (dry season). Color indices were evaluated three times during the rainy period (January, March, and April), and the $\mathrm{N}$ concentration in the leaves of the forage was determined in two rainy periods (January and March) and once during the dry period (August and September), over the 2-year evaluation.

Plant height was determined before each forage harvest using a measuring tape. This variable was measured from soil level to the highest leaf at five points of the usable area of each plot. Tiller density was measured using $0.25 \mathrm{~m} 2$ metal frames that were allocated at points representative of the pasture conditions (average height) upon sampling. Using the data obtained from the count of tillers present within the metal frame, we calculated tiller density (tillers $\mathrm{m}-2$ ).

To determine the yield, the forage plant was collected using a $1.0 \times 0.30 \mathrm{~m}$ iron frame and cut with steel scissors at a height of $0.20 \mathrm{~m}$ from the soil. Next, the material was weighed (fresh matter) and one sample was placed in a paper bag and dried in forced-air ovens for $72 \mathrm{~h}$ at a temperature of $65^{\circ} \mathrm{C}$. Next, the fresh matter of the sample was determined and the total dry matter collected in the plot was determined and extrapolated to yield/ha.

Regarding color indices, the relative chlorophyll content (RCC) using a chlorophyll meter and the hue and dark of the green color index obtained by digital imaging were evaluated. The chlorophyll meter (ClorofiLOG) readings were taken before each forage harvest at the middle third of two fully expanded leaves from the apex of the plant using 20 plants per plot. Digital images were also obtained before forage harvest, using a 12.0-mega pixel digital camera fixed at the extremity of an invertedL-shaped structure such that the images would be captured parallel to the grass surface. Reading were taken at the same height $(1.6 \mathrm{~m})$ and followed the method described by Godoy et al. (2012). Each image was analyzed using Corel PhotoPaint software v. 10.410 by recording the mean values of the red, green, and blue components (RGB) of the image obtained in the histogram. Because only the green (G) component defined green color, it also depended also on the red (R) and blue (B) components. RGB results were compiled into an Microsoft Excel spreadsheet and converted to HSB (hue, saturation, and brightness) values, as described by Godoy (2005). After the HSB values were obtained, the dark green color index (DGCI) was calculated using the following equation: DGCI $=[(\mathrm{H}-$ $60) / 60)+(1-\mathrm{S})+(1-\mathrm{B})] / 3$, where $\mathrm{H}=$ hue in degrees, ranging from $60 \hat{\mathrm{A}}^{\circ}$ (yellow) and $120 \hat{\mathrm{A}}^{\circ}$ (green); $\mathrm{S}=$ saturation in decimals; and $\mathrm{B}$ (brightness) $=$ brightnes $\mathrm{s}$ in decimals.

The obtained data were subjected to an analysis of variance. The effects of $\mathrm{N}$ rates were evaluated by regression analysis, using the magnitude of the regression coefficients as a criterion for the choice of model (with significance set at $5 \%$ probability). Sisvar software version 5.6 (Ferreira 2014) was used for these statistical analyses. The correlations between the indices of nitrogen $(\mathrm{N})$ content in leaves, and RCC, DGCI, H, and dry matter production of Paiaguás grass during all cycles were calculated using $\mathrm{R}$ software (RStudio Team, 2020).

\section{Results and Discussion}

The response of height of Paiaguás grass to $\mathrm{N}$ rates during the 1st cycle fitted a quadratic regression model in all cases (Figure 2).

In the 1st and 2nd growth cycles, one and two of the three applications of fertilizer were performed, respectively. $\mathrm{N}$ was only applied in the 3 rd growth cycle $\left(0,75,150,300\right.$, and $\left.600 \mathrm{~kg} \mathrm{ha}^{-1}\right)$. 
During the rainy period of the 1 st cycle, the equations suggested a maximum height of $96 \mathrm{~cm}$ for the $\mathrm{N}$ rate of $127 \mathrm{~kg} \mathrm{~N} \mathrm{ha}^{-1}$ in the 1st growth period ( $\left.\mathrm{p}<0.01\right) ; 81 \mathrm{~cm}$ for $190 \mathrm{~kg} \mathrm{ha}^{-1}(\mathrm{p}<0.01)$ in the 2 nd growth period; and 79 $\mathrm{cm}$ for $202 \mathrm{~kg} \mathrm{~N} \mathrm{ha}^{-1}(\mathrm{p}<0.05)$ in the 3rd growth period, indicating an increase in height with $\mathrm{N}$ rate in each growth period during initial plant development.

In the 4th growth period, which corresponded to the dry period, the $\mathrm{N}$ rate that provided the greatest height $(36 \mathrm{~cm})$ was $327 \mathrm{~kg} \mathrm{ha}^{-1}$, although that height was lower than those found in the other growth periods and required more N. This may be explained by the lack of water in the soil, which could lead to an inefficient mineralization process, reduced soil solution, and a consequent decline in $\mathrm{N}$ availability.

In the 2 nd cycle, the response was quadratic for the 1st, 2nd, and 3rd growth periods and linear in the 4th growth period (Figure 2). The $\mathrm{N}$ rates that provided the greatest heights in the 1st, 2nd, and 3rd growth periods were $102 \mathrm{~kg} \mathrm{ha}^{-1}(74 \mathrm{~cm})(\mathrm{p}<0.05), 232 \mathrm{~kg} \mathrm{ha}^{-1}(78 \mathrm{~cm})$ $(\mathrm{p}<0.01)$, and $350 \mathrm{~kg} \mathrm{ha}^{-1}(67 \mathrm{~cm})(\mathrm{p}<0.01)$, respectively. Greater heights that occurred in the 1st and 2nd growth periods in the 2 nd cycle could be explained by the residual effect of fertilization during the previous cycle, which was associated with good climatic conditions (Figure 1). The development of forage stabilized in the 3rd growth period. In the dry season (4th growth period), the response was linear as a function of the $\mathrm{N}$ rate, with a height near $42 \mathrm{~cm}$ with the highest evaluated $\mathrm{N}$ rate of $600 \mathrm{~kg} \mathrm{~N} \mathrm{ha}^{-1}(\mathrm{p}<0.01)$.

The density of tillers responded in a quadratic manner in both cycles and in all growth periods, as seen in Figure 3 . In the first cycle, the $\mathrm{N}$ rates that provided the greatest density of tillers the 1st $(p<0.01)$, 2nd $(p<0.01)$, 3rd $(p<0.05)$, and 4th $(p<0.01)$ growth periods were 116, 159, 173 , and $253 \mathrm{~kg} \mathrm{~N} \mathrm{ha}^{-1}$, respectively.

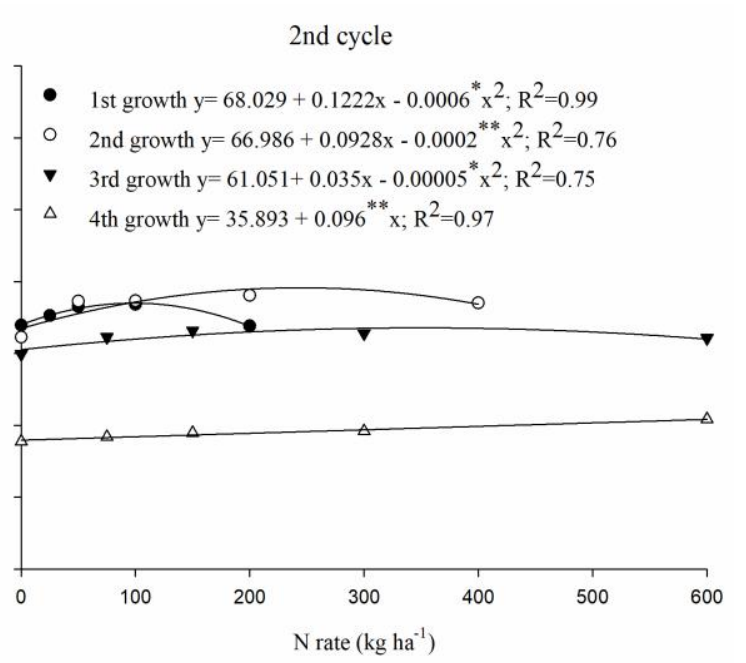

Figure 2. Height of Paiaguás grass subjected to various nitrogen rates in the 1st, 2nd, and 3rd (rainy), and 4th (dry) growth periods over 2 years (cycles) of evaluation.
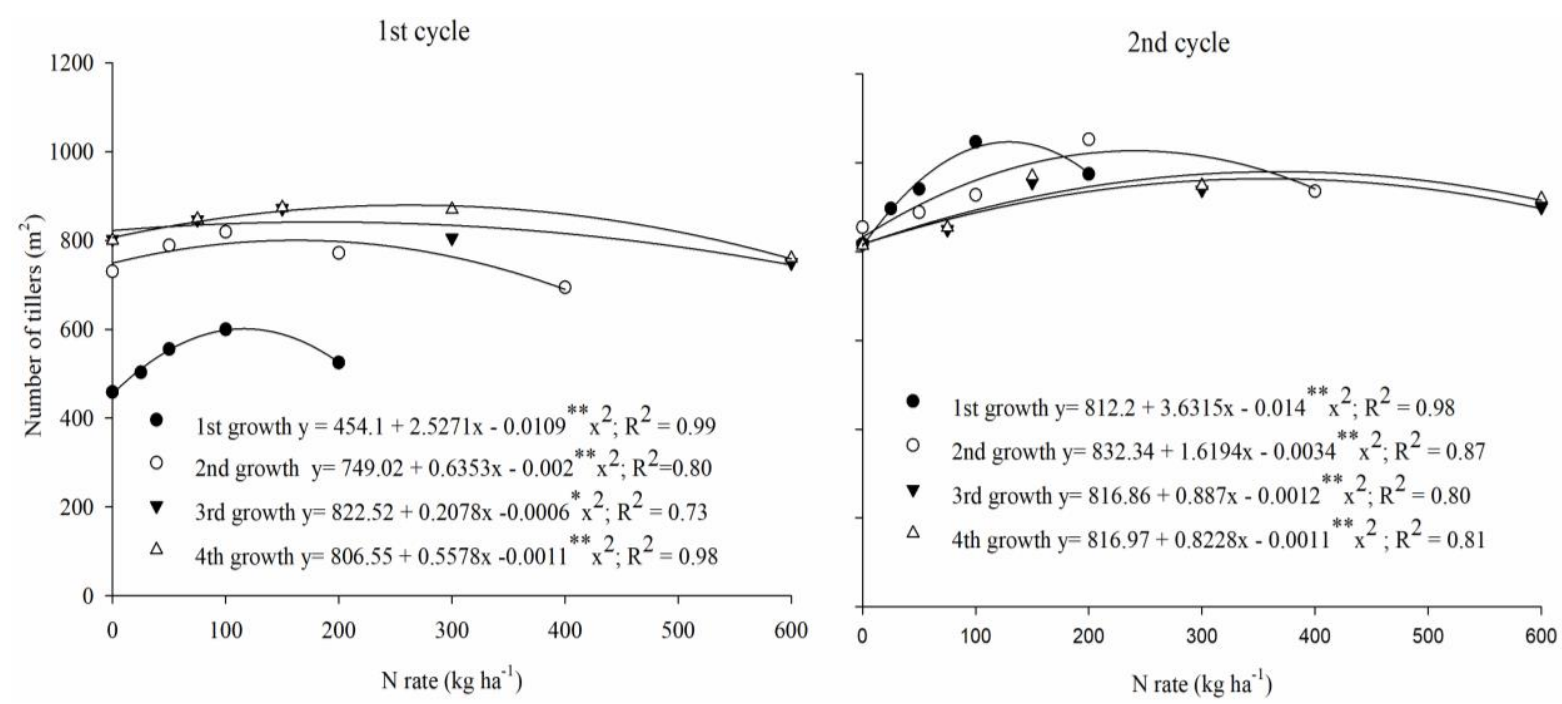

Figure 3. Number of tillers $\mathrm{m}^{-2}$ in Paiaguás grass subjected to various nitrogen rates in the 1st, 2nd, 3rd (rainy period), and 4th (dry period) growth periods during the first and second evaluation year (cycle). 
Regarding Paiaguás palisade grass height Germano et al. (2018) on Dystrophic Oxysoil, $\mathrm{N}$ rates between 0 to $250 \mathrm{~kg} \mathrm{ha}^{-1}$ were evaluated and they observed quadratic responses with the greatest height of $0.59 \mathrm{musing} 210 \mathrm{~kg}$ $\mathrm{ha}^{-1}$. Froehlich et al. (2019) using the same soil, grass, and $\mathrm{N}$ rate, observed a greater height of $0.63 \mathrm{~m} 150 \mathrm{~kg}$ $\mathrm{ha}^{-1}$ of $\mathrm{N}$.

Bezerra et al. (2019) using Paiaguás palisade grass in the Mato Grosso state region obtained heights between 53.55 and $55.48 \mathrm{~cm}$ at 30 and $60 \mathrm{~d}$ after sprouting during tests using wood ash as a fertilizer in soils under water stress. Rodrigues et al. (2021) using the same grass studied the establishment stage, which resulted in heights of $57 \mathrm{~cm}$ at $105 \mathrm{~d}$ after sprouting using $55 \mathrm{~kg} \mathrm{~N} \mathrm{ha}^{-1}$ in Quartizarenic Neosoil. Based on this information, it can be concluded that the height of Paiaguás palisade grass observed in this study corroborated that observed in the literature under different planting and fertilization conditions.

In figure 3 , in the first cycle, the $\mathrm{N}$ rates that provided the greatest density of tillers the $1 \mathrm{st}(\mathrm{p}<0.01)$, 2nd $(\mathrm{p}<0.01)$, 3rd $(\mathrm{p}<0.05)$, and 4 th $(\mathrm{p}<0.01)$ growth periods were $116,159,173$, and $253 \mathrm{~kg} \mathrm{~N} \mathrm{ha}^{-1}$, respectively. Tiller density followed the same order, being 600, 800, 840 , and 877 tillers $\mathrm{m}^{-2}$ in the 1st, 2nd, 3rd, and 4th growth periods, respectively The growing response up to the 3rd growth period can be explained by the initial development of the grass and the decline in the 4th growth period can be attributed to the end of the rainy period.

In the second cycle, the 1 st $(\mathrm{p}<0.01)$, 2nd $(\mathrm{p}<0.01)$, 3rd $(p<0.01)$, and 4th $(p<0.01)$ harvest periods exhibited maximum $\mathrm{N}$ rates of $130,238,370$, and $374 \mathrm{~kg} \mathrm{ha}^{-1}$ and $1,048,1,025,981$, and 956 tillers $\mathrm{m}^{-2}$, respectively. These responses were more discrete than in the first cycle, likely because of the advanced development of the plants.

Germano et al. (2018) and Froehlich et al. (2019) in area with Dystrophic Red Oxisol, tested Paiaguás palisade grass with $\mathrm{N}$ fertilization rates of 0 and $250 \mathrm{~kg} \mathrm{ha}^{-1}$. They observed a linear response in the increase tiller density with 440 and 571 tillers $\mathrm{m}^{-2}$, respectively. The densities were lower than those observed in our experiments, but our rate of applied $\mathrm{N}$ was larger and demonstrated had a quadratic response in tiller density with a greater density noted with applied rates up to $300 \mathrm{~kg} \mathrm{ha}^{-1}$ of N.

Dry matter (DM) yield (Figure 4) responded quadratically to $\mathrm{N}$ rates in both cycles and all harvest periods $(\mathrm{p}<0.01)$. In the first cycle, the $\mathrm{N}$ rates that provided the maximum DM yield in the 1st, 2nd, 3rd, and 4th harvest periods were $123,216,299$, and $321 \mathrm{~kg} \mathrm{ha}^{-1}$, producing 5,449, 6,334, 5,652, and 3,832 kg DM ha-1, respectively. In the second cycle, the maximum $\mathrm{N}$ rates for the 1st, 2nd, 3rd, and 4th harvest periods were 142, 223, 354, and $326 \mathrm{~kg} \mathrm{~N}$ ha $^{-1}$, respectively, generating respective DM yields of 3,452,4,132, 2,847, and 3,306 $\mathrm{kg} \mathrm{ha}^{-1}$.

Only the DM observed in the 3rd harvest period of the 2nd cycle was lower than that obtained in the dry season. This might have been influenced by precipitation (Figure 1), given that the last rains in 2016 occurred at the end of March and the interval between the second and third harvest periods was shorter (approximately $40 \mathrm{~d}$ ) than that between the 3 rd and 4th harvest periods.

Orrico Júnior et al. (2018) using Paiaguás palisade grass in a study in southern Brazil in Dystrophic Red Oxisol soil, tested organic fertilization with doses equivalent to $\mathrm{N}$ from 0 to $1200 \mathrm{~kg} \mathrm{ha}^{-1}$. They showed that accumulated production before four cuts at the higher dose yielded the maximum production of $23,200.00 \mathrm{~kg}$ $\mathrm{ha}^{-1} \mathrm{DM}$. In the present study, during the 1st cycle, a greater yield of $21,061.69 \mathrm{~kg}$ was obtained with $328 \mathrm{~kg}$ $\mathrm{ha}^{-1} \mathrm{~N}$. Therefore, similar results were obtained, although the tests occurred in different geographic regions and with different sources of $\mathrm{N}$.

Germano et al. (2018) and Froehlich et al. (2019), who also tested Paiaguás palisade grass in Red Oxisol soil, observed a linear response in DM yield up to $250 \mathrm{~kg}$ $\mathrm{ha}^{-1}$ of $\mathrm{N}$, which was the maximum rate of $\mathrm{N}$ tested. Productivity was from $5,860.00$ to $8,127.00 \mathrm{~kg} \mathrm{ha}^{-1}$ of DM, respectively. Thus, production was lower in our study than in these studies and this is likely attributed to the minor rates of $\mathrm{N}$ tested. This attests to the response of Paiaguás palisade grass to doses higher than $250 \mathrm{~kg} \mathrm{ha}^{-1}$ of $\mathrm{N}$.

Relative chlorophyll content (RCC), as determined using a chlorophyll meter, responded quadratically to $\mathrm{N}$ rates in all growth periods in the 1st and 2nd cycles, except for the 3rd growth period in the 1 st cycle, when it had a linear response, as illustrated in Figure 5.

In the $1 \mathrm{st}(\mathrm{p}<0.01)$ and $2 \mathrm{nd}(\mathrm{p}<0.01)$ growth periods of the first cycle, the $\mathrm{N}$ rates that led to the highest RCC were 119 and $318 \mathrm{~kg} \mathrm{ha}^{-1}$, respectively, whereas in the 3rd growth period the highest RCC occurred with the highest evaluated $\mathrm{N}$ rate of $600 \mathrm{~kg} \mathrm{ha}^{-1}$. In the second cycle, in the 1st $(\mathrm{p}<0.01)$, 2nd $(\mathrm{p}<0.01)$, and 3rd $(\mathrm{p}<0.05)$ growth periods, the $\mathrm{N}$ rates were 116,261 , and $390 \mathrm{~kg} \mathrm{~N} \mathrm{ha}^{-1}$, respectively. Higher chlorophyll content was observed in the first cycle in comparison with the second, likely because of the initial development of the plant.

The RCC can be employed as an indicator of $\mathrm{N}$ nutritional status of the forage, although its use is not suggested during the dry period (Costa et al. 2015). It could also be a parameter for use in establishing the recommended nitrogen fertilization (Yu-Sen et al. 2015). Furthermore, use of the chlorophyll meter is a fast, making it a practical tool that causes no harm to the plant (Rigon et al. 2012) 


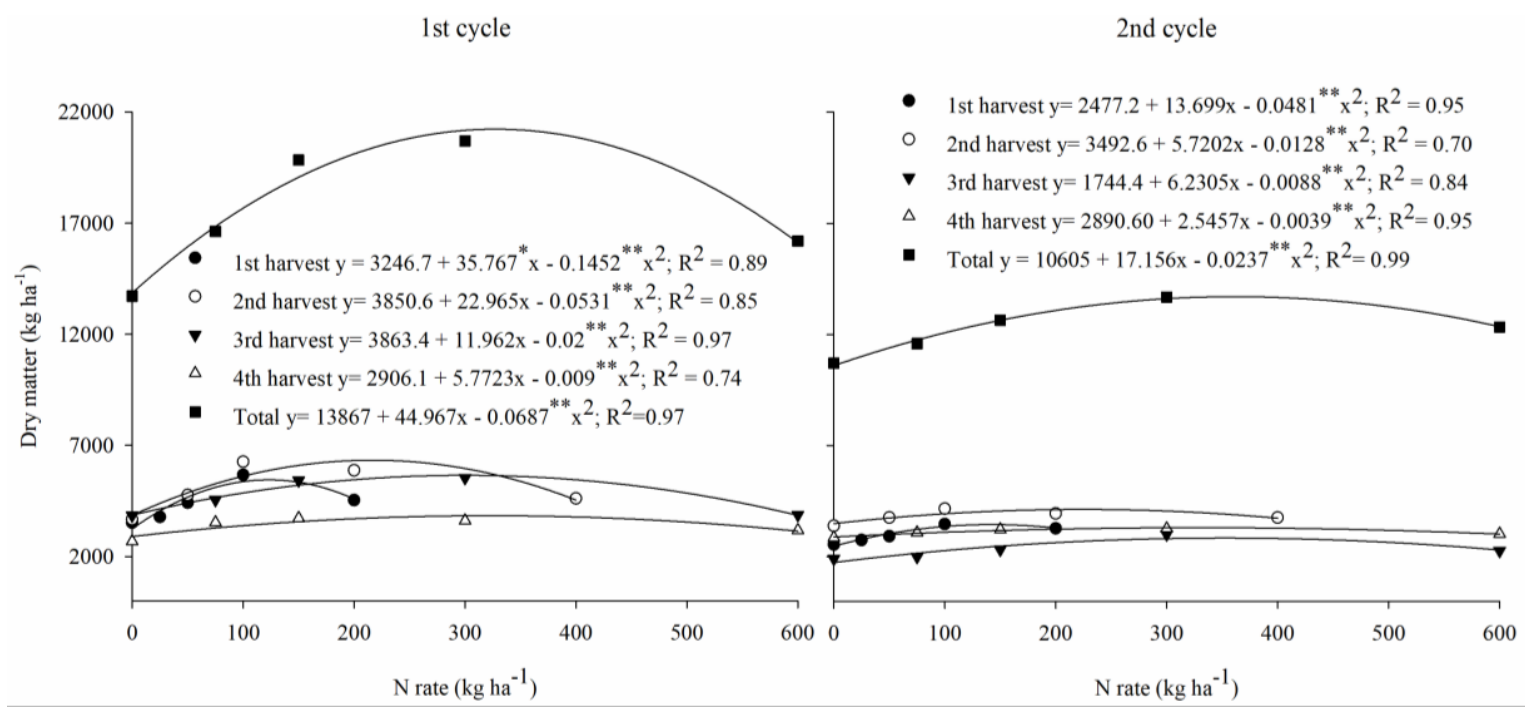

Figure 4. Shoot dry matter of Paiaguás grass subjected to nitrogen rates in the 1st, 2nd, 3rd (rainy period), and 4th (dry period) harvest periods in the first and second evaluation cycles.
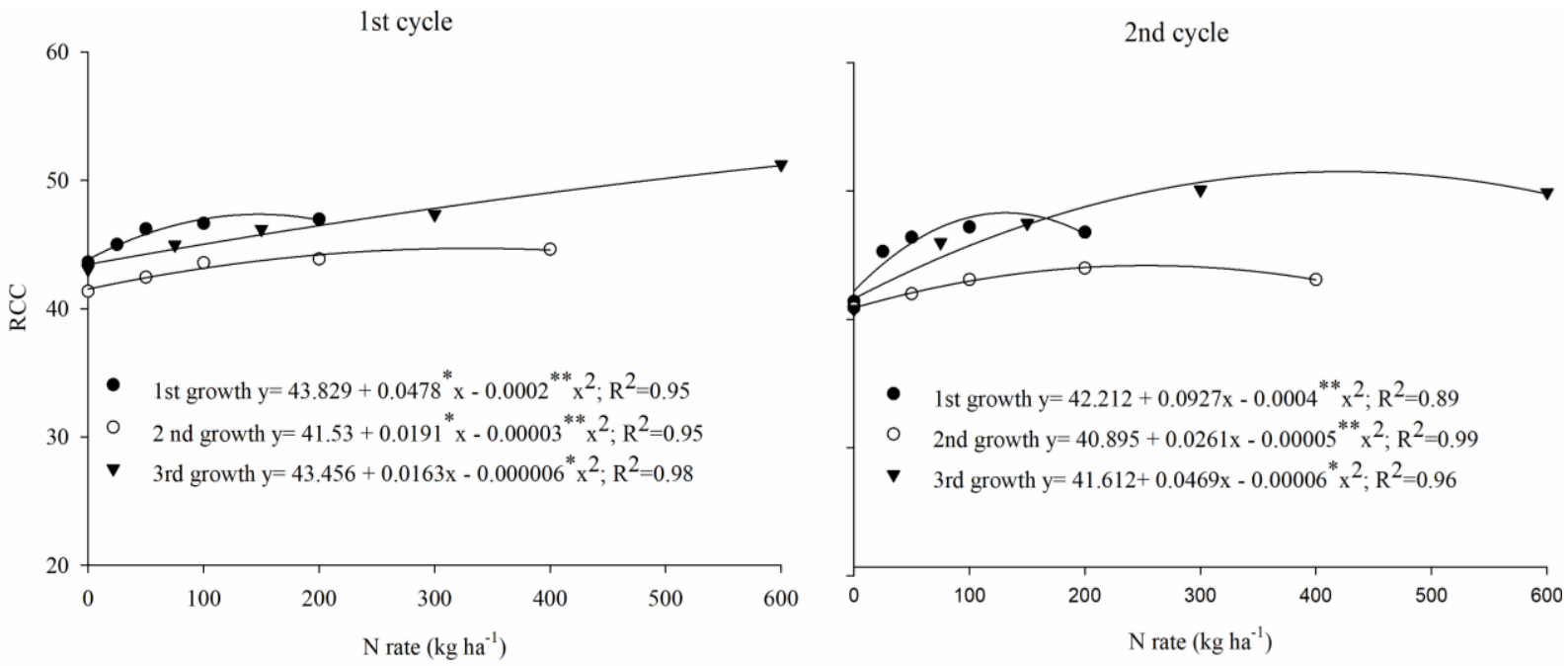

Figure 5. Relative chlorophyll content (RCC) in the leaves of Paiaguás grass subjected to various nitrogen rates in the 1st, 2nd, and 3rd (rainy period) growth periods in the first and second evaluation cycles.

Bezerra et al. (2019) studied Paiaguás palisade grass in Dystrophic Red Oxisol with wood ash fertilization in soil under water stress. They observed an RCC of 41 and 48 with wood ash doses equivalent to $150 \mathrm{~kg}$ ha-1 of $\mathrm{N}$. The values they obtained were similar to that found in this study, although the RCC response to tested doses increased with $\mathrm{N}$ rates above $250 \mathrm{~kg}$ ha- 1 after the second cut, as noted in Figure 5. Epifanio et al. (2019) studied intercropping with Stylosanthes Campo Grand and Paiaguás palisade grass under similar soil conditions during all seasons of the year. They detected an RCC of 36.57 when Paiaguás palisade grass was cultivated alone and an RCC of 42.21 when it was intercropped with Stylosanthes. These data support the increment in RCC because of $\mathrm{N}$ provided by the legume.

Of the indices obtained by digital imaging (Figure 6), the green color hue $(\mathrm{H})$ in the 1st cycle responded quadratically in the 1 st growth period $(\mathrm{p}<0.01)$, responding up to the $\mathrm{N}$ rate of $178 \mathrm{~kg}$ ha- 1 with $89^{\circ}$. In the second growth period, this variable responded linearly $(p<0.01)$, whereas no regression model fit $\mathrm{H}$ in the $3 \mathrm{rd}$ growth period. In 1st growth period of the second cycle, $\mathrm{H}$ also did not fit any regression model, but the response was quadratic in the 2 nd $(\mathrm{p}<0.01)$ and $3 \mathrm{rd}(\mathrm{p}<0.01)$ growth periods, with maximum $\mathrm{H}$ values $\left(94^{\circ}\right.$ and $\left.129^{\circ}\right)$ obtained at the respective $\mathrm{N}$ rates of 238 and $291 \mathrm{~kg} \mathrm{~N}$ ha- 1 .

The obtained $\mathrm{H}$ values of $89^{\circ}$ and $129^{\circ}$ indicated that the grass remained green during the rainy period with nitrogen fertilization. In forage, $\mathrm{H}$ values near $60^{\circ}$ indicate leaf chlorosis, which can be caused by a nutritionaldeficit for $\mathrm{N}$ as a consequence of decreased chlorophyll concentration (Backes et al. 2010). In figure 7, for the dark green color index (DGCI), also obtained by digital imaging, responses were linear in the first and second cycles in the 1st growth period up to the highest application rate of $\mathrm{N}(\mathrm{p}<0.01)$. 

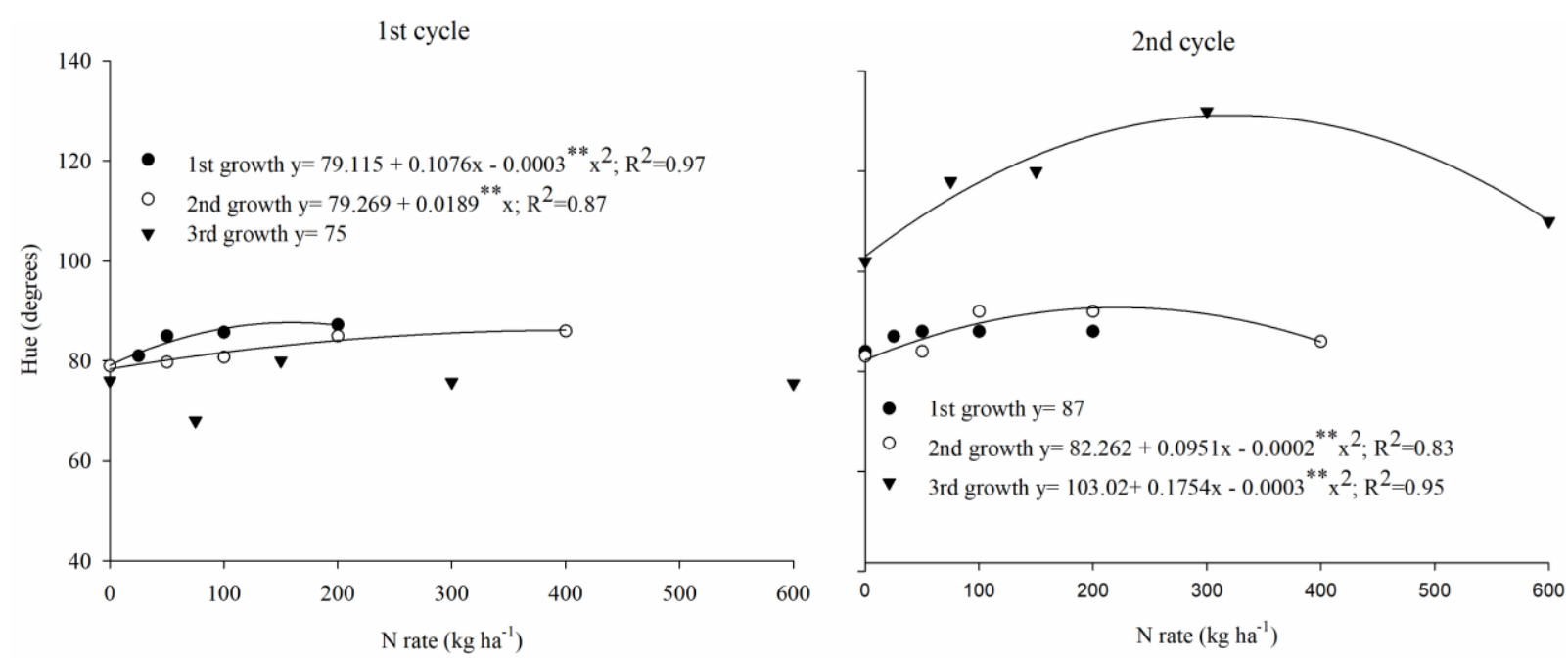

Figure 6. Hue $(\mathrm{H})$ of leaves of Paiaguás grass subjected to various nitrogen application rates in the 1st, 2nd, and 3rd (rainy period) growth periods in the first and second evaluation cycles.
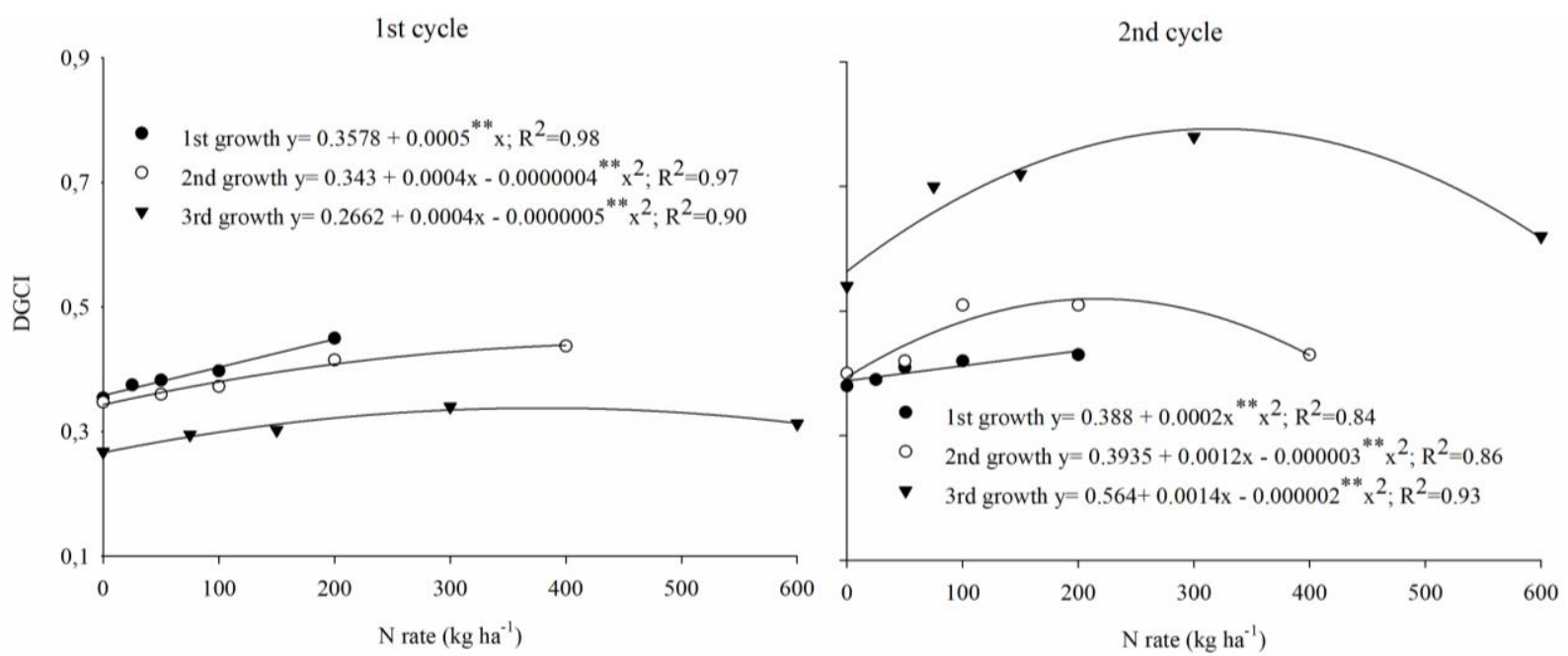

Figure 7. Dark green color index (DGCI) in the leaves of Paiaguás grass subjected to various nitrogen rates in the 1st, 2nd, and 3rd (rainy period) growth periods in the first and second evaluation cycles.

In the first cycle (Figure 7) the response was quadratic in the 2nd and 3rd growth periods, with the highest values obtained at estimated $\mathrm{N}$ rates of 500 $(\mathrm{p}<0.01)$ and $400(\mathrm{p}<0.01) \mathrm{kg} \mathrm{ha}^{-1}$, respectively. In the 2nd and 3rd growths of the second cycle, DGCI responded quadratically, with the highest values at the respective $\mathrm{N}$ rates of $200(\mathrm{p}<0.01)$ and $350(\mathrm{p}<0.01) \mathrm{kg}$ $\mathrm{ha}^{-1}$.

The highest DGCI was observed in the 1st growth period of the first cycle and in the 3rd growth period of the second cycle, suggesting that the grass became greener in the second cycle and it was maintained longer. Lima et al. (2012) reported that the H and DGCI indices are positively correlated with plant $\mathrm{N}$ content and could be used as parameters for use in determining recommended nitrogen fertilization of Bermuda grass.

Therefore, the capacity of Paiaguás grass to remain green after the harvest, as occurred in the second cycle, interferes with the $\mathrm{N}$ accumulation ability of the plant tissues. Of the green color indices, which responded to nitrogen fertilization at all evaluation times, RCC, obtained with the chlorophyll meter, and DGCI, obtained with digital imaging, responded to nitrogen fertilization.

The choice of method depends on the cost of equipment and time needed to process the analyses. Gazola et al. (2016) stressed that digital imaging analysis is more efficient than the use of a chlorophyll meter in $\mathrm{N}$-fertilization recommendations.

Although the chlorophyll meter takes only one reading at a time, the captured image makes it possible to evaluate larger areas. Moreover, the chlorophyll meter incurs an expense for the purchase of the equipment, although processing of digital imaging requires instruction and adequate software to extract the indices. 
The obtained indices (values) cannot be used the same for different soil-climatic conditions. In the words of Lima et al. (2012), a reference area under the same soil and climatic conditions should be used to receive a higher $\mathrm{N}$ rate and to serve as a parameter for decisions regarding the best time for fertilization. Nitrogen concentration in gras $\mathrm{s}$ leaves as a function of $\mathrm{N}$ rates is depicted in Figure 8. In the 4th growth period of the first cycle, no model fit; however, in the 1st and 2nd growth periods, a linear response was observed. No model fit the 1st growth period in the second cycle, which had growing N concentrations up to the $\mathrm{N}$ rate of $600 \mathrm{~kg} \mathrm{ha}^{-1}(\mathrm{p}<0.01)$.

In the second cycle, a quadratic response was detected in the 2 nd and 4 th growth periods, and the maximum $\mathrm{N}$ concentrations of 23 and $25 \mathrm{~g} \mathrm{~kg}^{-1}$ were obtained with $\mathrm{N}$ rates of $347(\mathrm{p}<0.01)$ and $388(\mathrm{p}<0.01)$ $\mathrm{kg} \mathrm{ha}^{-1}$, respectively. The higher concentration of $\mathrm{N}$ occurring in the dry period (4th growth) suggests an adaptation of Paiaguás grass to be used for animal feeding during this critical production time. Oliveira et al. (2021) studied Paiaguás palisade grass and reported an $\mathrm{N}$ content of $24.83 \mathrm{~g} \mathrm{~kg}^{-1}$ in cropped grass that previously had silage implanted in a crop-livestock system. The grassland was fertilized with $36 \mathrm{~kg} \mathrm{ha}^{-1} \mathrm{~N}$ for $30 \mathrm{~d}$ after sprouting.

Therefore, under different conditions, the results resembled those obtained in this study, although the greater supply of $\mathrm{N}$ produced higher $\mathrm{N}$ content in fourth growth period of second cycle, resulting in $25.21 \mathrm{~g} \mathrm{~kg}^{-1}$ of $\mathrm{N}$ with $388 \mathrm{~kg} \mathrm{ha}^{-1}$ application of N. Figure 9 shows that the RCC and digital image index ( $\mathrm{H}$ and DGCI) of Paiaguás palisade grass was significantly correlated with foliar $\mathrm{N}$ content, as determined in the lab, during both cycles
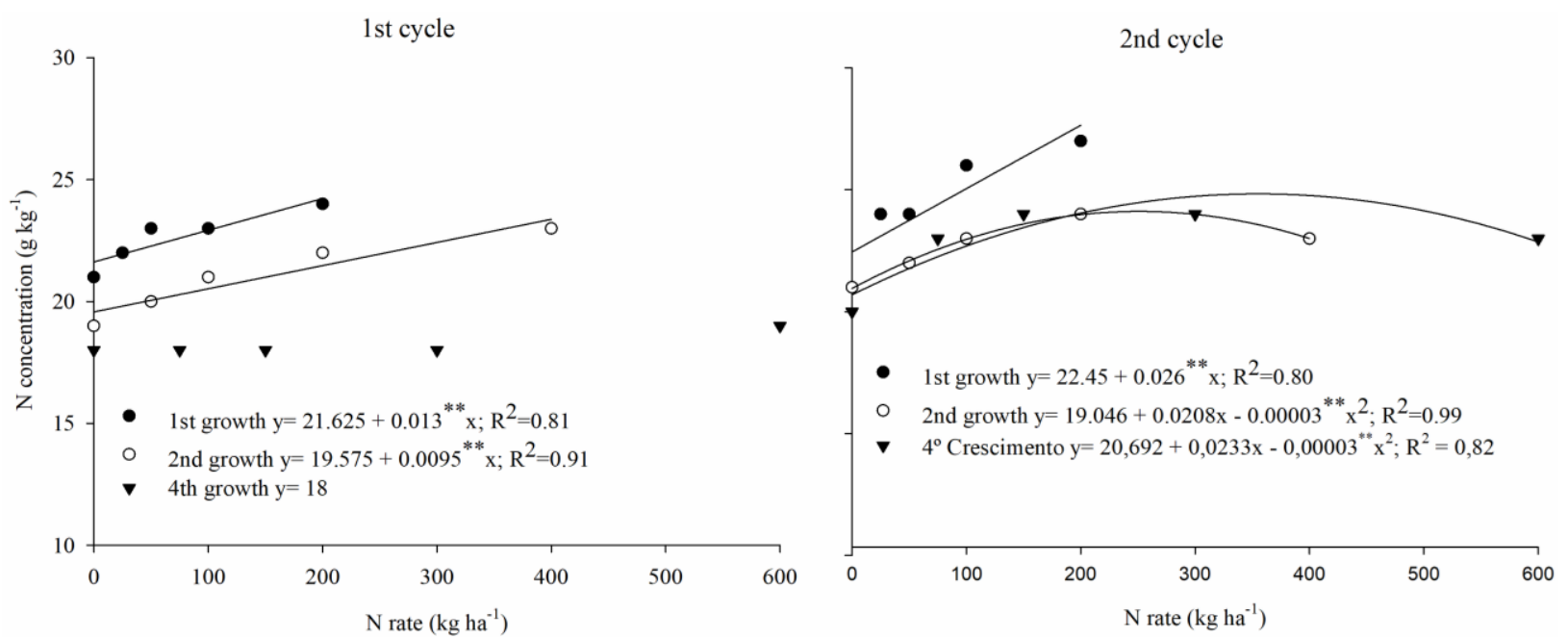

Figure 8. Nitrogen concentration in the leaves of Paiaguás grass subjected to various nitrogen rates in the 1st, 2nd (rainy period), and 4th (dry period) growth periods in the first and evaluation second cycles.
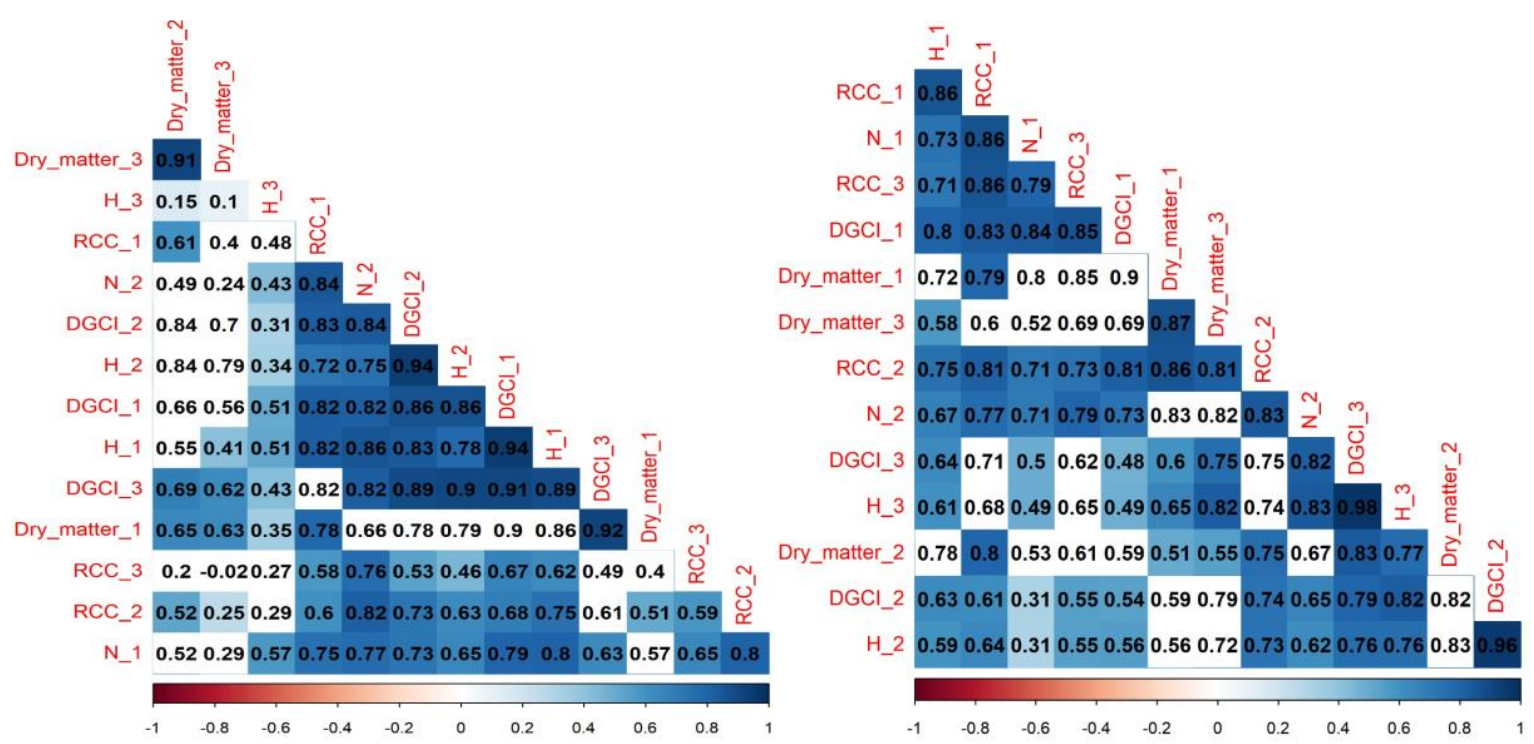

Figure 9. Correlation between parameters of digital images (H, DGCI) and RCC with the N foliar content and dry matter y ield for the three cuts in the two evaluated cycles.

*Dry_matter_1,2, and 3: Dry matter from 1st, 2nd, and 3rd cycles; H_1,2, and 3: Hue (H) from 1st, 2nd, and 3rd cycles; DGCI_1, 2, and 3: Dark Green Color Index from the 1st, 2nd, and 3rd cycles; RCC_1, 2, and 3: Relative Chlorophyll Content (RCC) from 1st, 2nd, and 3rd cycles; N_1, 2, and 3: Nitrogen (N) from 1st, 2nd, and 3rd cycles. 
Generally, the index was moderately to highly correlated with DM yield. In the first cycle, the digital image indexes were more strongly correlated with DM yield than was RCC or N foliar content. During the second cycle, all indexes were highly correlated with DM yield, mainly DGCI, which on average, had a higher correlation coefficient for the three cuts.

Lima et al. (2021) and Backes et al. (2010) both studied Zoysia janpônica fertilized with nitrogen and domestic sewage sludge, respectively. They observed strong positive correlations between DGCI and RCC with $\mathrm{N}$ content in vegetation tissue.

This behavior was similar to that found in this study, as shown in Figure 9. Moreover, other relationships were noted between DGCI and RCC with DM yield, which could be related to the importance of $\mathrm{N}$ in chlorophyl composition and the photosynthetic process, and consequently, higher production of DM during our evaluation.

Therefore, the strong correlation between DGCI and RCC with DM yield and $\mathrm{N}$ leaf content of Paiaguás palisade grass was in parallel with nitrogen fertilization. It is possible to infer that using these parameters as a reference for this species to diagnosis the nutritional state of grasslands and plan nitrogen fertilization management is efficient, practical, and economically feasible because it allows fast analysis and requires few resources compared to laboratory analysis.

\section{Conclusions}

Paiaguás grass responded to an $\mathrm{N}$ rate up to $374 \mathrm{~kg}$ $\mathrm{ha}^{-1}$ for production-related traits, such as plant height, density of tillers, and shoot DM.

The maximum DM yields obtained were 21,225 and $13,710 \mathrm{~kg} \mathrm{ha}^{-1} \mathrm{yr}^{-1}$ in the first and second cycles, respectively.

Both the chlorophyll meter and digital imaging were efficient in indicating the $\mathrm{N}$ nutritional status of the plants, data supported by correlation analysis.

\section{Authors' Contribution}

Authors Alexandre A. Domingues, as an academic in Masters degree, was oriented by advisors Clarice Backes and Alessandro J. M. Santos, who were the project's creators.

Those already mentioned with the authors Arthur G. Teodoro, Lucas M. Rodrigues, Stephanie V. Bessa and Cinthya C. F. de Resende, were responsible for the implementation, conducting the experiment, collect and data analysis.
All authors together with the following: Adriana A. Ribon, Pedro R. Giongo and Leandro J. G. de Godoy assisted in the writing and review of this job.

\section{Bibliographic References}

Adbala, A.L., Louvandini, H., Bueno, I.C. S., Vitti, D.M.S.S., Meirelles, C.F., Gennari, S.M. 1999. Constrains to milk production in grazing dairy cows in Brasil and management strategies for improving their productivity. Preventive Veterinary Medicine, 38(2),217-230. DOI: https://doi.org/10.1016/S0167-5877(98)00127-5.

Alvares, C.A., STAPE, J.L., Sentelhas, P.C., Gonçalves, J.L.M., Sparovek, G. 2014. Köppen's climate classification map for Brazil. Meteorologische Zeitschrift, 22(6), 711- 728. DOI: https://doi.org/10.1127/0941-2948/2013/0507.

Backes, C., Villas-Bôas, R.L., Lima, C.P., Godoy, J.G., Büll, L.T., Santos, A.J.M. 2010. Estado nutricional em nitrogênio da grama esmeralda avaliado por meio de teor foliar, clorofilômetro e imagem digital, em área adubada com lodo de esgoto. Bragantia, 69(3), 661-668. DOI: https://doi.org/10.1590/S0006-87052010000300018.

Bezerra, M.D., Bonfim-Silva, E.M., Silva, T.J.A., Ferraz, A.P.F., Damasceno, A.P.A.B. 2019. Phytometric Characteristics and Chlorophyll Index of "Paiaguás" grass (Urochloa Brizantha) as a function of whood ash doses and soil water stress. Australian Journal of Crop Science, 13(11), 18831891. DOI: https:// doi.org/10.21475/ajcs.19.13.11.p2100.

Costa, E.M., Slva, H.F., Ribeiro, P.R.A. 2013. Matéria orgânica do solo e seu papel na manutenção e produtividade dos sistemas agrícolas. Enciclopédia Biosfera, 9(17), 1842-1860.

Costa, J.P.R., Caputti, G.P., Galzerano, L., Silva, W.L., Da, Ruggieri, A.C., Malheiros, E.B. 2015. Relative chlorophyll contents in the evaluation of the nutritional status of nitrogen from xaraes palisade grass and determination of critical nitrogen sufficiency index. Acta Scientiarum Animal Sciences, 37(2),109114. DOI: https://doi.org/10.4025/actascianimsci.v37i2.24854.

Detmann, E., Paulino, M.F., Valadares Filho, S.C., Huhtanen, P. 2014. Nutritional aspects applied to grazing cattle in the tropics: a review based on brasilian results. Semina: Ciências $\begin{array}{llll}\text { Agrárias,04(1), } 2829 \quad- & 2854 . & \text { DOI: }\end{array}$ https://doi.org/10.5433/1679-0359.2014v35n4Suplp2829.

DIAS-FILHO, M.B. 2014. Diagnósticos das pastagens no Brasil. Belém, Embrapa Amazônica Oriental.

EMBRAPA. EMPRESA BRASILEIRA DE PESQUISA AGROPECUÁRIA. 2013. Produtos, Processos e Serviços: Brachiaria brizantha - BRS Paiaguás. https://www.embrapa.br/busca-de-produtos-processos-eservicos/-/produto-servico/892/brachiaria-brizantha---brspaiaguas (accessed June 10, 2021)

Epifanio, P.S., Costa, K.A.P., Severiano, E.C., Simon, G.A., Silva, V.R. 2019. Nitrogen nutrition and changes in the chemical attributes of the soil for cultivars of Brachiaria brizantha intercropped with stylosantes in different forage systems. Archives of Agronomy and Soil Science, 66(8), 11541169. DOI: https://doi.org/10.1080/03650340.2019.1658867. 
Ferraz, J.F.S., Felício, P.E. 2010. Production systems - Na example from Brazil. Meat Science, 84(1), 238 - 243. DOI: http://doi:10.1016/j.meatsci.2009.06.006.

Ferreira, D.F. 2014. Sisvar: a Guide for its Bootstrap procedures in multiple comparisons. Ciência e Agrotecnologia, 38 (2). DOI: http://dx.doi.org/10.1590/S1413-70542014000200001.

Froehlich, G.C., Vendruscolo, M.C., Alves, D.S., Mexi, A.A. 2019. Produtividade de Brachiaria Brizantha cv. BRS Paiaguás em diferentes doses de nitrogênio. Campo Digital, 14(1), 22-34.

Gazola, R.P.D., Buzetti, S., Gazola, R.N., Castilho, R.M.M., Teixeira-Filho, M.C.M., Celestrino, T.S., Dupas, E. 2016. Nitrogen and type of herbicide used for growth regulation on the green coloration intensity of Emerald grass. Ciência Rural, 46(6),984-990. DOI: https://doi.org/10.1590/0103$8478 \mathrm{cr} 20150276$.

Germano, L.H.E., Verdruscolo, M.C., Daniel, D.F., Dalbianco, A.B. 2018. Produtividade e Características Agronômicas de Brachiaria brizantha cv. Paiaguás Submetida a Doses De Nitrogênio sob Cortes. Boletim de Indústria Animal, 75(1), 114. DOI: https://doi.org/10.17523/bia.2018.v75.e1419.

Godoy, L.J.G. 2005. Adubação nitrogenada para produção de tapetes de grama santo agostinho e Esmeralda [thesis]. São Paulo, Faculdade de Ciências Agronômicas. Universidade Estadual de São Paulo, Botucatu.

Godoy, L.J.G., Villas Bôas, R.L., Backes, C. 2012. Produção de tapetes de grama Santo Agostinho submetida a doses de nitrogênio. Semina: Ciências Agrárias, 33(5), 1703-1716. DOI: https://doi.org/10.5433/1679-0359.2012v33n5p 1703.

Golçalves, L.C., Borges, I., Ferreira, P.D.S. 2009. Alimentação de Gado de Leite. FEPM VZ, Belo Horizonte.

IBGE. INSTITUTO BRASILEIRO DE GEOGRAFIA E ESTATÍSTICA. 2020a. Pesquisa Trimestral do Abate de Animais.

https://www.ibge.gov.br/estatisticas/economicas/agricultura-epecuaria/9203-pesquisas-trimestrais-do-abate-deanimais.html?edicao $=30317 \& \mathrm{t}=$ destaques (accessed June 29, 2021).

IBGE. INSTITUTO BRASILEIRO DE GEOGRAFIA E ESTATÍSTICA 2020b. Pesquisa Trimestral do Leite. https://www.ibge.gov.br/estatisticas/economicas/agricultura-epecuaria/9209-pesquisa-trimestral-do-leite.html?=\&t=o-que-e (accessed June 29, 2021).

Lima, C.P., Backes, C., Fernandes, D.M., Santos, A.J.M.S., Godoy, L.J.G., Villas-Bôas, R.L. 2012. Uso de índices de reflectância das folhas para avaliar o nível de nitrogênio em grama-bermuda. Ciência Rural, 42(9), 1568-1574. DOI: https://doi.org/10.1590/S0103-84782012005000062.

Mcroberts, K.C., Benson, B.M., Mudrak, E.L., Parsons, D., Cherney, D.J.R. 2016. Application of local binary patterns in digital images to estimate botanical composition in mixed alfafafrass fields. Computers and Eletronics in Agriculture, 23(1), 95 103. DOI: https://doi.org/10.1016/j.compag.2016.02.015.
Oliveira, N.C., Costa, K.A.P., Rodrigues, L.G., Silva, A.C.G., Costa, J.V.C.P., Silva, S.A.A., Assis, L.F.A., Oliveira, S.M.P., Vieira, M.L. 2021. Fermentation characteristics and nutritite value of sweet sorghum silage with Paiaguas palisadegrass and Ip y ora grass. Semina: Ciências Agrárias, 42(3), 1923-1940. DOI: http://dx.doi.org/10.5433/1679-0359.2021v42n3Sup11p 1923.

Orrico Junior, M.A.P., Silveira, A.P., Orrico, A.A., Schwingel, A.W., Carnavali, P.L.C., Alves, D.C. 2018. Use of organic compost for the fertilization of piatã and paiaguás grasses: effects of dose on morphogenic, structural, nutritional and productive characteristics. Compost Science \& Utilization, 26(3), 201-208. DOI: https://doi.org/10.1080/1065657X.2018.1457998.

Raij, B.V., Andrade, J.C, Cantarella, H., Quaggio, J.A. 2001. Análise química para avaliaçaõ da fertilidade de solos tropicais, Instituto Agronômico, Campinas.

RStudio Team. 2020. RStudio: Integrated Development for R. RStudio, PBC, Boston, MA http://www.rstudio.com/. (accessed june 10, 2021).

Reis, R.A., Ruggieri, A.C., Casagrande, D.R., Páscoa, A.G. 2009 Suplementação da dieta de bovinos de corte como estratégia do manejo das pastagens. Revista Brasileira de Zootecnia, 38(slp),147-159. DOI: https://doi.org/10.1590/S151635982009001300016.

Rigon, J.P.G., Beltrão, N.E.M., Capuani, S., Neto, J.F.B., Silva, F.V.F. 2012. Análise não destrutiva de pigmentos fotossintéticos em folhas de gergelim. Revista Brasileira de Engenharia Agrícola e Ambiental, 16(3), 258-261. DOI: https://doi.org/10.1590/S1415-43662012000300004

Rodrigues, J.G., Difante, G.S., Gurgel, A.L.C., Veras, E.L.L., Costa, A.B.G., Pereira, M.G., Emerenciano Neto, J.V., Costa, C.M. 2021. Establishment of brachiaria cultivars in the soilclimatic conditions of the brazlian semi-arzid region. Acta Scientiarum Animal Sciences, 43(e51802), 1807-8672. DOI: https://doi.org/10.4025/actascianimsci.v43i1.51802.

Simões, C.R., Rossiello, R.O.P., Graciosa, M.G., Machado, M.L., Silva, C.F. 2015. Imagens multiespectrais para avaliação de índice de área foliar e massa seca do capim Tifton 85, sob adubação nitrogenada. Ciência Rural, 45(4), 697-703. DOI: https://doi.org/10.1590/0103-8478cr20131424.

USDA. UNITED STATES DEPARTAMENT OF AGRICULTURE. Livestock and Poultry: World Markets and Trade. 2017. Foreign Agricultural Service. https://apps.fas.usda.gov/psdonline/circulars/livestock_poultry .pdf. (acessed June, 04, 2017).

Viana, M.C.M., Silva, I.P., Freire, F.M., Ferreira, M.M., Costa, E.L., Mascarenhas, M.H.T., Teixeira, M.F.F. 2014. Production and nutrition of irrigated Tanzania guinea grass in response to nitrogen fertilization. Revista Brasileira de Zootecnia, 43(5), 238243. DOI: https://doi.org/10.1590/S1516-35982014000500003.

Yu-Sen, C., Yu-Shian, C., Yu-Jen, K. 2015. Use of a portable chlorophyll meter to evaluate leaf nitrogen status of tropical carpet grass. African Journal of Agricultural, 10(52), 47784782. DOI: http://doi.org/10.5897/AJAR2013.8070 